\title{
Differential Expression of $\beta$-1,3-Glucanase Transcripts Induced by Pathogens in the Leaves of Vitis flexuosa
}

\author{
Soon Young Ahn, Seon Ae Kim, Hae Keun Yun* \\ Department of Horticulture \& Life Science, Yeungnam University, Gyeongsan 712-749, Korea
}

\begin{abstract}
The differential expression of $\beta$-1,3-glucanase genes in the leaves of Vitis flexuosa induced by fungal and bacterial pathogen infections was investigated. The nucleotide and deduced amino acid sequences of $\beta$-1,3-glucanase genes from the transcripts of $V$. flexuosa were compared. The percentage similarity of deduced amino acid ranged from $22.0 \%$ between VfGlu34359 and VfGlu48103 to $96.9 \%$ in VvGlu2735 and VvGlu48103. To demonstrate the differential expression pattern of $\beta$-1,3-glucanase genes, primers specific to unique regions in each gene were obtained by alignment of the sequences. Accumulation patterns of $\beta$-1,3-glucanase mRNAs in the leaves of $V$. flexuosa were induced differentially and were dependent on the pathogens used including Botrytis cinerea, Colletotrichum acutatum, Elsinoe ampelina, and Rhizobium vitis. This study provides useful information that will improve our understanding of grapevine defense responses to various pathogen attacks.
\end{abstract}

Keywords Defense response, Fungal pathogen, Gene expression, PR protein, Rhizobium vitis

\section{INTRODUCTION}

In host-pathogen interactions, plants regulate defenses through physical and chemical responses that may occur either before or after pathogen infection. Induced defense mechanisms are involved in the transduction of various signals involved in the production of reactive oxygen species, phytoalexin biosynthesis, reinforcement of plant cell walls, and the accumulation of pathogenesis-related (PR) proteins, some of which possess antimicrobial properties (Kombrink and Somssich 1995; Fritig et al. 1998; Rivera et al. 2002; Gill and Tuteja 2010; Ibraheem et al. 2010; Huffaker et al. 2011). PR proteins that are induced by pathogen infection have been reported in wheat (Li et al. 2001), grapevine (Hatmi et al. 2013; Renault et al. 1996), mango (Ebrahim et al. 2011), banana (Harish et al. 2009), European plum (El-kereamy et al. 2011), and apple (Li et al. 2014).

$\beta$-1,3-glucanases are PR-2 proteins that catalyze endotype hydrolytic cleavage of $1,3-\beta$-D glycosidic linkages in $\beta$ $-1,3$-glucans present in the cell walls of many pathogenic fungi (Simmons 1994). Induction of $\beta$-1,3-glucanase has been reported in various plants infected with fungal pathogens including tomato (Joosten and De Wit 1989), wheat (Kemp et al. 1999), peach (Zemanek et al. 2002), rubber tree (Thanseem et al. 2005), apple (Venisse et al. 2002), rucola (Gupta et al. 2013), V. flexuosa (Ahn et al. 2012), and strawberry (Fang et al. 2012). It has been suggested that these compounds play multiple roles in plant defense response. They can degrade the cell wall of the pathogen directly or exert indirect defenses such as induction of the release of cell wall-derived components that act as elicitors of active defense reactions (Mauch et al. 1988; Yoshikawa et al. 1993).

Among Vitis species native to Korea, $V$. flexuosa was reported to show resistant responses such as expression of $\beta$-1,3-glucanase and glutathione- $S$-transferase genes (Ahn et al. 2012). In this study, $\beta$-1,3-glucanase transcripts expressed in different levels in the transcriptome from $V$. flexuosa inoculated with E. ampelina were obtained. The objectives of this study were to compare nucleotide and deduced amino acid sequences by alignment of $\beta-1,3-$

Received June 6, 2014; Revised June 19, 2014; Accepted June 23, 2014; Published June 30, 2014

*Corresponding author Hae Keun Yun, haekeun@ynu.ac.kr, Tel: +82-53-810-2942, Fax: +82-53-810-4659 
glucanase genes, and to analyze the differential expression against different pathogens such as Botrytis cinerea, $C$. acutatum, Elsinoe ampelina (culture filtrates and spore), and Rhizobium vitis in Vitis flexuosa.

\section{MATERIALS AND METHODS}

\section{Plant materials, pathogen preparation, and inoculation}

A Korean wild grape, Vitis flexuosa VISKO001, was obtained from the grapevine germplasm collection field of Yeungnam University, Gyeongsan. Cuttings of $V$. flexuosa VISKO001 were cultivated in an experimental glasshouse at $25^{\circ} \mathrm{C}$ under a $16 \mathrm{~h}$ photoperiod. The upper fourth or fifth leaves from the shoot apex of the plant were individually used for the pathogen inoculation, which was accomplished after lightly scratching the epidermis with a pencil tip.

B. cinerea was grown in petri-dishes at $25^{\circ} \mathrm{C}$ on potato dextrose agar (PDA, $0.4 \%$ potato starch, $2 \%$ dextrose, and $1.5 \%$ agar) under $12 / 12 \mathrm{~h}$ light/dark conditions. Spores of $B$. cinerea were collected from the plates, suspended in $0.24 \%$ potato dextrose broth at a concentration of $10^{6}$ spores $/ \mathrm{ml}$ and then centrifuged at $3,000 \mathrm{~g}$ for $5 \mathrm{~min}$ to remove mycelia debris. Leaves were inoculated by dropping $30 \mu \mathrm{l}$ of spore suspension on the wounded areas.

Virulent strain of C. acutatum Co601 isolated from infected leaves at the National Academy of Agricultural Science, RDA, Suwon, Korea was used for plant inoculation. C. acutatum were grown on PDA medium at $25^{\circ} \mathrm{C}$ under $12 / 12 \mathrm{~h}$ light/dark conditions, after which $30 \mu \mathrm{l}$ of spore suspensions $\left(10^{5}\right.$ spores $\left./ \mathrm{ml}\right)$ were dropped onto the abaxial portion of the leaf.

Several colonies of E. ampelina were incubated in a shaking incubator $(140 \mathrm{rpm})$ at $28^{\circ} \mathrm{C}$ for ten days. The cultures were then harvested by centrifugation, ground in a homogenizer in sterile distilled water, and poured onto V-8 juice agar medium ( $20 \% \mathrm{~V}-8$ juice, $2 \%$ agar) and incubated at $28^{\circ} \mathrm{C}$ under a near ultraviolet lamp for two days to produce spores of the pathogen (Yun et al. 2003). Spores of E. ampelina were harvested by scraping-off of plates with sterile distilled water. The concentration was then adjusted to $10^{5}$ spores $/ \mathrm{ml}$ and sprayed onto leaves. Next, the $E$. ampelina was incubated in PDB medium (potato dextrose broth) at $28^{\circ} \mathrm{C}$ for 21 days, after which cell-free culture filtrates (CFCF) were collected from the supernatant by centrifugation and sterilized by ultra-filtration $(0.2 \mu \mathrm{m}$ pore diameter). Finally, $30 \mu 1$ of E. ampelina culture filtrate was dropped onto the wounded portion of leaves.

A single colony of bacteria was placed in YEP medium ( $0.1 \%$ yeast extract, $0.5 \%$ beef extract, $0.5 \%$ peptone, $0.5 \%$ sucrose, $0.05 \% \mathrm{MgSO}_{4}, \mathrm{pH} 7.2$ ) and cultivated at $28^{\circ} \mathrm{C}$ in a shaking incubator, after which it was spun down by centrifugation and resuspended with sterile water. $R$. vitis cell suspension $(30 \mu \mathrm{l})$ was dropped onto the wounded portion of the leaves.

Leaves inoculated with the pathogens were placed on two layers of moist paper towel, then incubated in a closed box in a dark, moist chamber $(100 \% \mathrm{RH})$ at $25^{\circ} \mathrm{C}$ or $28^{\circ} \mathrm{C}$ for two days. Five leaves were used for each treatment, and the experiment was repeated twice. Controls were harvested from water-treated leaves under the same conditions. Leaves were harvested at the indicated time points $(0,1,6$, 24 , and $48 \mathrm{~h}$ ) after inoculation, immediately frozen in liquid nitrogen, and then stored at $-80^{\circ} \mathrm{C}$ for future use.

\section{RNA isolation and cDNA synthesis}

Frozen grapevine leaves $(1 \mathrm{~g})$ were ground in liquid nitrogen using a mortar and pestle. RNA was then isolated using a modified version of the method described by Chang et al. (1993). The quality of total RNA was measured based on the absorbance at 230, 260, and $280 \mathrm{~nm}$ using a Nano Drop spectrophotometer (ND-1000, Technologies Inc., Wilmington, DE, USA). First-strand cDNA was then synthesized from the total RNA (500 ng) using a GoScript ${ }^{\mathrm{TM}}$ Reverse Transcription System (GoScript ${ }^{\mathrm{TM}}$ Reverse Transcription System, Promega, Madison, WI, USA) and subsequently used as a template for PCR.

\section{Cloning and sequence analysis}

Nucleotide sequences were translated using the Translate program hosted by the ExPASy Proteomics Server (http:// au.expasy.org). Pairwise comparisons and multiple alignments of nucleotide and deduced amino acid sequences were performed using ClustalX (Thompson et al. 1997). A 
phylogenetic tree was constructed by the neighbor-joining method using Mega 4.0 (Fig. 2).

\section{Real-time PCR analysis}

Real-time PCR was performed on a $\mathrm{C} 1000^{\mathrm{TM}}$ Thermal Cycler (CFX96 ${ }^{\mathrm{TM}}$ Real-Time System, BioRad, Hercules, CA, USA) using SYBR Premix Ex (SYBR Premix Ex Taq, TaKaRa Bio Inc., Osaka, Japan) as the fluorescent dye. Amplification was conducted by subjecting the samples to one cycle at $95^{\circ} \mathrm{C}$ for $30 \mathrm{~s}$, followed by 40 cycles of $95^{\circ} \mathrm{C}$ for $5 \mathrm{~s}$ and $60^{\circ} \mathrm{C}$ for $30 \mathrm{~s}$. Transcript levels were calculated using the standard-curve method and normalized against the grapevine actin gene (AB372563) as an internal control and non-treated leaves (at time zero) as the reference sample, after which melting curves of the amplified products were recorded. For each gene, the reference sample was defined as the $1 \mathrm{x}$ expression level, and results were expressed as the fold increase in mRNA over the reference sample. All reactions were performed in triplicate.

Among 28 DEGs identified upon transcriptome analysis of $V$. flexuosa inoculated with E. ampelina (Ahn et al. 2014), six loci showing variation with more than 100 transcripts were selected for evaluation of their differential expression against pathogen attacks. Four of these $\beta-1,3-$ glucanase genes showed differential expression in response to $E$. ampelina inoculation of grapevines, therefore, specific primers for real-time PCR were designed by alignment of the nucleotide sequences obtained from the $V$. flexuosa transcriptome data. Nucleotide sequence data of the $V$. flexuosa transcript loci 2735, 5391, 34359, and 48103 have

Table 1. Sequences of primers used for real-time PCR analysis in this study.

\begin{tabular}{|c|c|c|}
\hline Name & $\begin{array}{l}\text { Accession no. } \\
\text { or NABIC }{ }^{\mathrm{z})} \text { ID }\end{array}$ & Primer sequences \\
\hline$\beta$-1,3-glucanase 1 & DQ267748.1 & $\begin{array}{l}\text { 5'-GGGTTTTTATTGGCAACCCTTC-3' } \\
\text { 5'-GCTACCACTTGTGATGCTGGTG-3' }\end{array}$ \\
\hline $\begin{array}{c}\beta \text {-1,3-glucanase } 2 \\
\text { (Locus 2735-VfGlu2735) }\end{array}$ & NS-0399-000001 & $\begin{array}{l}\text { 5'-CGTTCAGAGTGCAATAACCTCCT-3' } \\
\text { 5'-CGAGGACGGCTGAATATGTTG-3' }\end{array}$ \\
\hline $\begin{array}{c}\beta \text {-1,3-glucanase } 1 \\
\text { (Locus 5391- VfGlu5391) }\end{array}$ & NS-0400-000001 & $\begin{array}{l}\text { 5'-GCTTGACCTCAGGGTAGTGGAA-3' } \\
\text { 5'-TCAAGGTGGGCAGGCTTAGTAG-3' }\end{array}$ \\
\hline $\begin{array}{c}\beta \text {-1,3-glucanase } 1 \\
\text { (Locus 34359- VfGlu34359) }\end{array}$ & NS-0402-000001 & $\begin{array}{l}\text { 5'-GAATCTCGATCAGGCCTTGAGA-3' } \\
\text { 5'-GAACTGCAGTGGAAAAGCTGGT-3' }\end{array}$ \\
\hline $\begin{array}{c}\beta \text {-1,3-glucanase } 1 \\
\text { (Locus 48103- VfGlu48103) }\end{array}$ & NS-0401-000001 & $\begin{array}{l}\text { 5'-GCGATGTAGCGGAACTTCACTT-3' } \\
\text { 5'-AGCTACCTGGGTGCAAAACAAC-3' }\end{array}$ \\
\hline VACT & AB372563 & $\begin{array}{l}\text { 5'-ACGAGAAATCGTGAGGGATG-3' } \\
\text { 5'-ATTCTGCCTTTGCAATCCAC-3' }\end{array}$ \\
\hline
\end{tabular}

${ }^{\mathrm{z})} \mathrm{NABIC}$ - National Agricultural Biotechnology Information Center, RDA, Korea.

Table 2. Identity of deduced amino acid from alignment of $\beta$-1,3-glucanase (Glu) genes of $V$. flexuosa transcripts. Glu proteins and accession numbers: VvGlu (DQ267748.1), VfGlu2735 (Locus 2735, NS-0399-000001), VfGlu5391 (Locus 5391, NS-0400-000001), VfGlu34359 (Locus 34359, NS-0402-000001), and VfGlu48103 (Locus 48103, NS-0401-000001).

\begin{tabular}{cccccc}
\hline \hline & VvGlu & VfGlu2735 & VfGlu5391 & VfGlu34359 & VfGlu48103 \\
\hline VvGlu & & 59.8 & 58.4 & 49.0 & 55.3 \\
VfGlu2735 & 59.8 & & 59.3 & 50.4 & 96.9 \\
VfGlu5391 & 58.4 & 59.3 & & 48.5 & 46.0 \\
VfGlu34359 & 49.0 & 50.4 & 48.5 & & 22.0 \\
VfGlu48103 & 55.3 & 96.9 & 46.0 & 22.0 & \\
\hline
\end{tabular}


been deposited in the NABIC (National Agricultural Biotechnology Information Center, RDA, Korea) database with the respective accession numbers NS-0399-000001, NS-0400-000001, NS-0402-000001, and NS-0401-000001. The $\beta$-1,3-glucanase primer sequences are listed in Table 1 . The deduced amino acid sequences of $\beta$-1,3-glucanase genes between $V$. flexuosa transcripts were compared using the CLC Main Workbench (Ver. 4.0, CLC Bio, Aarhus, Denmark).

\section{RESULTS}

The deduced amino acid sequences of $\beta$-1,3-glucanase genes in $V$. flexuosa transcripts are shown in Fig. 1. Using the deduced amino acid sequences of $\beta-1,3$-glucanase genes, the percent similarity ranged from $22.0 \%$ for VfGlu34359 and VfGlu48103 to $96.9 \%$ for VvGlu2735 and VfGlu48103.
The similarity value of the other transcript pairs were $59.8 \%$ between VfGlu and VfGlu2735, 50.4\% between VvGlu2735 and VfGlu34359, and $46.0 \%$ in VfGlu5391 and VfGlu48103 (Table 2).

Based on pairwise comparisons and multiple alignments of nucleotide and deduced amino acid sequences, a phylogenetic tree was constructed by the neighbor-joining method using Mega 4.0 (Fig. 2). The results revealed a close relationship between VvGlu, VfGlu5391, VfGlu2735, and VfGlu48103.

Specific primers for $\beta$-1,3-glucanase genes designed based on alignment of nucleotide sequences from $V$. flexuosa transcripts were used to detect differential expression in grapevine leaves inoculated with pathogens by real-time PCR. The accumulation patterns of $\beta$-1,3-glucanase mRNA were induced differentially and were dependent on several pathogens tested in this study (Fig. 3). In grapevine leaves inoculated with $B$. cinerea, the expression of VvGlu and VfGlu2735 was rapidly up-regulated, peaking at $24 \mathrm{~h}$. The

\begin{tabular}{|c|c|c|c|c|}
\hline VvGlu & 1 & \multicolumn{2}{|c|}{ 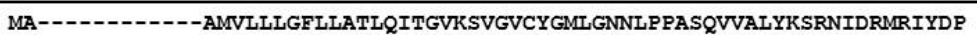 } & 57 \\
\hline VfGlu2735 & & \multicolumn{2}{|c|}{ MALT---RNKP-L-VVVLLLGEVIMSTLTIGAQSIGVCYGTNGDNLPSASQVINLYKSNGIGSMRIYDP } & 54 \\
\hline VfGlu5391 & 1 & \multicolumn{2}{|c|}{ MTVNSYVKSSPRMTTVLLLIGLL-MTSLHLTETOIGVCYGTLGDNLPPPEEVVVELYTRNNFORMRLYDP } & 68 \\
\hline VfGlu34359 & 1 & \multicolumn{2}{|c|}{ 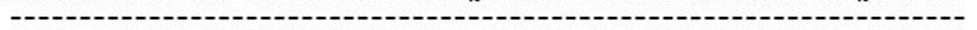 } & 0 \\
\hline vfGlu48103 & 1 & \multicolumn{2}{|c|}{ MALT---RNKP-L-VVVLLLGFVIMSTLTIGAQSIGVCYGTNGNNLPSASQVINLYKSNGIGSMRIYDP } & 64 \\
\hline VvGlu & 58 & \multicolumn{2}{|c|}{ NQAALQALRGSNIQLMLGVPNSDLQGLATNPSQAQSWVQRNVRNYWPGVSFRYIAVGNEVSPVNGGTSR } & 126 \\
\hline VfGlu2735 & 65 & \multirow{2}{*}{\multicolumn{2}{|c|}{$\begin{array}{l}\text { NSDTLQALKGSGIELILDVPNTSLQSLASDASDASTWVQNNVVNYASDVKFRYIAAGNEVLPT-GSNAQ } \\
\text { NIAALRALGGSNIFLILSVPNNDIODIAASOGIANLWVOAYVTNYT-KVKFRYIAVGNIVSPS-D---S }\end{array}$}} & 132 \\
\hline vfGlu5391 & 69 & & & 132 \\
\hline vfGlu34359 & 1 & \multicolumn{2}{|c|}{$\begin{array}{c}-1-1 \\
-1\end{array}$} & 0 \\
\hline VfGlu48103 & 65 & \multicolumn{2}{|c|}{ NSDTLQALKGSGIELILDVPNTDLQSLASDASAAATWVQNNVVNYASEVKFRYIAVGNEVLPT-GSNAQ } & 132 \\
\hline 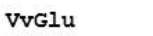 & 27 & \multicolumn{2}{|c|}{ FAQFVLPAMRNIRAALASAGLQDRVKVSTAIDLTLLGNSYPPSQGAFRGDVRGYLDPIIRFLVDNKSPL } & \\
\hline VfGl & 33 & \multicolumn{2}{|c|}{ YAQYVLPAMKNVQSAITSAGLQGQIKVSTATYSSVLGTSYPPSAGSFSSDVSSFINPIISFLAENGSPI } & 201 \\
\hline vfG] & 133 & \multirow{2}{*}{\multicolumn{2}{|c|}{$\begin{array}{l}\text { FAQFLLPAMKNINNAISAAGLHNQIKVSTAINTGVLGTSYPPSQGSFQTQARSFLDPIISLLVENRAPL } \\
-\end{array}$}} & 201 \\
\hline 4359 & 1 & & & 61 \\
\hline VfGlu48103 & 133 & \multicolumn{2}{|c|}{ YAQYVLPAMKNVQS̃ SATT- } & 149 \\
\hline Vve & 196 & \multicolumn{2}{|c|}{ LANIYPYFGYSGNPKDISLPYALFTANSVVVWDGQRGYKNLFDAMLDALYSALGRAGGASLEVVVSESG } & 264 \\
\hline VfGlu2735 & 202 & \multicolumn{2}{|c|}{ LANIYPYFSYTGNTQSIQLDYALFTSPEVVVKDGSYQYQNLFDALIDALYAALGKAGGSNLKIVVSESG } & 270 \\
\hline VfGlu5391 & 202 & \multicolumn{2}{|c|}{ LVNLYPYLSYSANTQDVSLDYALFTANEVTVQDGQIGYRNLFDSMVDAFYSALEKAGGSSLEIVISESG } & 270 \\
\hline 34359 & 62 & \multicolumn{2}{|c|}{ LVNVYPYFSYINDPVNVPLDYALFNSSRVVVRDGELEYKNLFDAIADATYTALEKAGGASVKVVVTESG } & \\
\hline VfG] & 150 & \multicolumn{2}{|c|}{ - } & 149 \\
\hline VvGlu & 265 & \multicolumn{2}{|c|}{ WPS-AGGFGTTVDNARTYNSNLIRHVKG--GTPKRPGRAIETYLFAMFDENKKEP-QLEKHFGLFFPNK } & 329 \\
\hline VfGlu2735 & 271 & \multicolumn{2}{|c|}{ WPS-EGGTAATVDNARTYYKNLINHVKG--GTPRKSG-AIETYLFAMFDENQKTGLETEKHFGLFTPSQ } & 335 \\
\hline VfGlu5391 & 271 & \multicolumn{2}{|c|}{ WPS-AGGTGATLDNARIYNTNLIQHVKG--GTPKRPGKAIETYVFAMFDENRKTP-ELERHWGLFLPNK } & 335 \\
\hline VfGlu34359 & 131 & \multicolumn{2}{|c|}{ WPSNENGQIATIENARMYNNNLVAHLSGAKGTPKKPGESIEAYVFAIFNEDLKPR-GTEQNFGLYYPNM } & 198 \\
\hline VfGlu48103 & 150 & \multicolumn{2}{|c|}{ - } & 149 \\
\hline VvGlu & 330 & QPKYSINFSGEKPWDVSTENDTNEESLKSDI & 360 & \\
\hline vfGlu2735 & 336 & 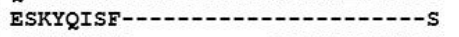 & 344 & \\
\hline vfGlu5391 & 336 & QSKYPLICR----------IPSATQIVYSIV & 356 & \\
\hline vfGlu34359 & 199 & 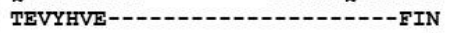 & 208 & \\
\hline VfGlu48103 & 150 & (5) & 150 & \\
\hline
\end{tabular}

Fig. 1. Multiple amino acid sequence alignment of $V$. flexuosa $\beta$-1,3-glucanase (Glu) transcripts using the CLC Main Workbench (Ver. 4.0, CLC Bio, Aarhus, Denmark). Vv: Vitis vinifera, Vf: Vitis flexuosa. Glu proteins and accession numbers: VvGlu (DQ267748.1), VfGlu2735 (Locus 2735, NS-0399-000001), VfGlu5391 (Locus 5391, NS-0400-000001), VfGlu34359 (Locus 34359, NS-0402-000001), and VfGlu48103 (Locus 48103, NS-0401-000001). 
expression of VfGlu5391, VfGlu48103, and VfGlu34359 was also up-regulated, peaking at $6 \mathrm{~h}$ after pathogen inoculation.

The mRNA levels of VvGlu, VfGlu5391 and VfGlu34359 were upregulated, reaching the peak values at $1 \mathrm{~h}$ and $24 \mathrm{~h}$ after inoculation with $C$. acutatum. In both leaves inoculated with spore suspensions of E. ampelina and then treated with their culture filtrates, the expression of VfGlu34359 was down-regulated while VvGlu and VfGlu2735 was up-regulated, peaking at $48 \mathrm{~h}$ and $6 \mathrm{~h}$, respectively. In the case of leaves inoculated with $R$. vitis, the mRNA level of VfGlu34359 was down-regulated, which is similar to the results observed with E. ampelina inoculation treatment. The VvGlu showed the maximum level of transcripts at $24 \mathrm{~h}$ after $R$. vitis inoculation, while VfGlu2735 and VfGlu48103 showed two peaks at $1 \mathrm{~h}$ and $24 \mathrm{~h}$ after pathogen inoculation.

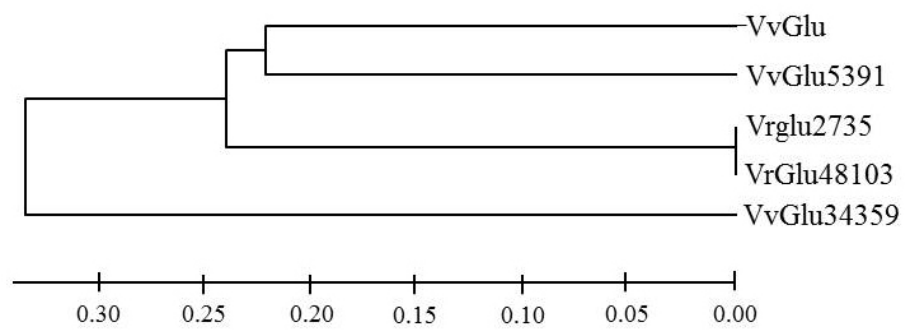

Fig. 2. Phylogenetic tree of VvGlu (DQ267748.1) and other $\beta$-1,3-glucanase proteins from Vitis flexuosa transcripts VfGlu2735 (Locus 2735, NS-0399-000001), VfGlu5391 (Locus 5391, NS-0400-000001), VfGlu34359 (Locus 34359, NS-0402-000001), and VfGlu48103 (Locus 48103, NS-0401-000001).

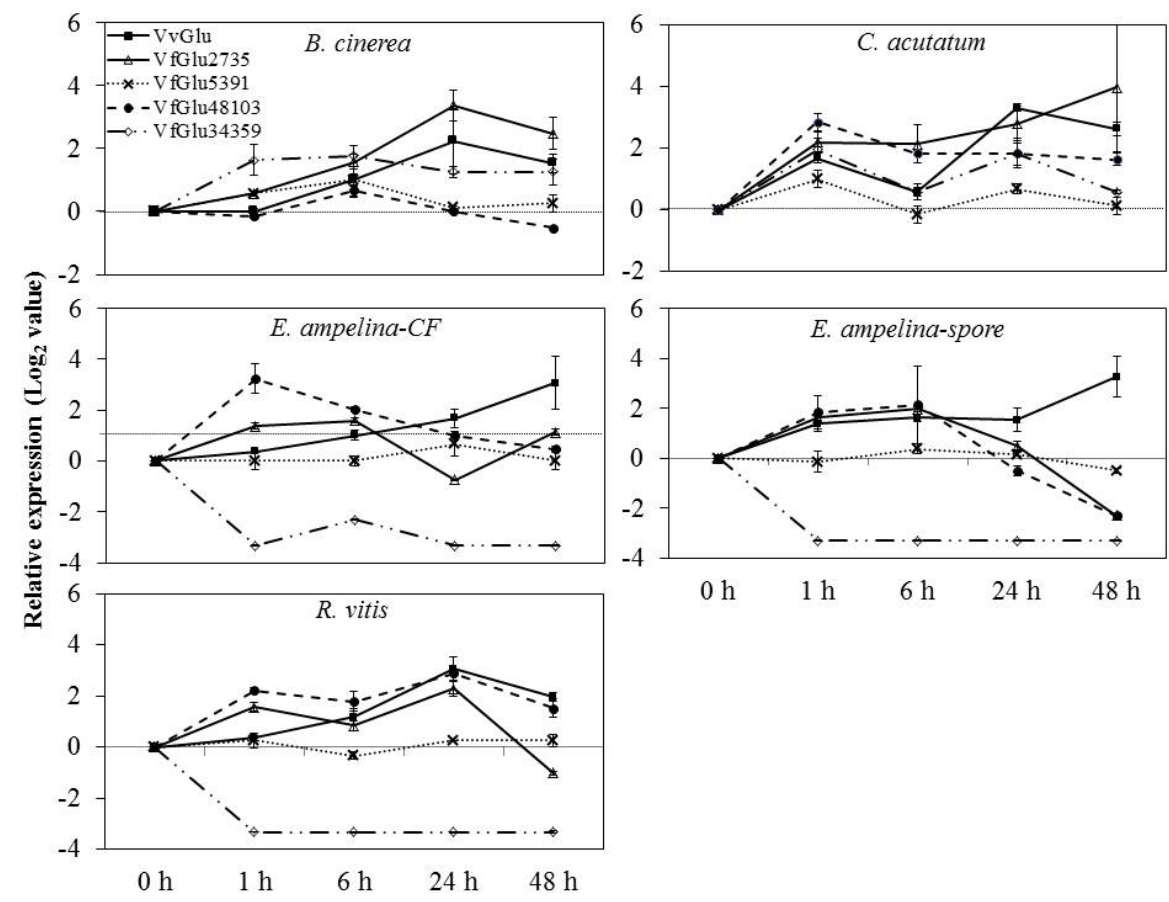

Fig. 3. Expression of $\beta-1,3$-glucanase (Glu) genes by quantitative real-time PCR analysis of $V$. flexuosa leaves inoculated with pathogens. Transcript levels were calculated using the standard curve method from triplicate data with the grapevine actin gene as an internal control and non-treated leaves (at time zero) as a reference sample. The results represent the mean fold increase in mRNA level over non-treated leaves relative to the $1 \mathrm{x}$ expression level. Results are the means of triplicate data from three experiments. Bars indicate the standard deviation. VvGlu (DQ267748.1), VfGlu2735 (Locus 2735, NS-0399-000001), VfGlu5391 (Locus 5391, NS-0400-000001), VfGlu34359 (Locus 34359, NS-0402-000001), and VfGlu48103 (Locus 48103, NS-0401-000001). 


\section{DISCUSSION}

Accumulation of PR proteins, such as $\beta$-1,3-glucanase, is one of the most common markers of actively induced plant defense response. The fact that $\beta$-1,3-glucanase is induced by a broad range of biotic and abiotic factors suggests that it plays a general role in plant defense (Zemanek et al. 2002). However, there is a limited number of studies focused on expression of various $\beta-1,3$-glucanase transcripts with differences in nucleotide sequences within a single plant species responding to different pathogens to date. In this study, five $\beta$-1,3-glucanase genes were used to demonstrate their expression in response to five different pathogens which are causal agents of the major grapevine diseases in Korea.

To investigate the differential expression patterns of $\beta$ -1,3-glucanase genes, primers specific to unique regions in each gene were obtained by alignment of the sequences. Real-time PCR analysis showed that pathogen inoculation resulted in upregulated mRNA levels of $\beta$-1,3-glucanase genes in $V$. flexuosa leaves. Induction of $\beta$-1,3-glucanase in response to various pathogens such as Plasmopara viticola (Kortekamp 2006), B. cinerea (Renault et al. 1996), Sphaerotheca fusca (Rivera et al. 2002) and Erysiphe necator (Giannakis et al. 1998) has been thoroughly investigated in several plants, and the timing and level of transcripts has been reported to vary between pathogens and genotypes. In this study, even though there was little variation in the expression level and onset of response, $\beta$ -1,3-glucanase mRNA levels were shown to increase in response to inoculation of five pathogens.

Culture filtrates (CF) have been used in screening for resistance (Jayasankar et al. 2000; Yun et al. 2006). Zemanek et al. (2002) reported that mRNA levels increased following treatment of CFs with bacterial and fungal pathogens. The $\mathrm{CF}$ of $E$. ampelina used in the present study has been found to induce $\beta$-1,3-glucanase mRNA transcripts of $V$. flexuosa. Different or multiple production pathways of $\beta-1,3$-glucanases may be involved in different responses to the diseases caused by several fungal pathogens (Cheong et al. 2000; Krishnaveni et al. 1999; Roulin and Buchala 1995). Zemanek et al. reported (2002) that $\beta$-1,3-glucanase can act as a preformed protein or be induced as a specific or nonspecific defense protein against different pathogens. In the present study, we elucidated nucleotide and deduced amino acid sequences specific for $\beta$-1,3-glucanase genes differentially expressed in $V$. flexuosa in response to several pathogens.

$\beta$-1,3-glucanases genes comprise a large gene family that has been subdivided into three major classes based on their primary structures (Neale et al. 1990; Payne et al. 1990; Ward et al. 1991). It has been reported that plants express $\beta$-1,3-glucanase genes (I, II, and III) in response to fungal and viral infections (Dobnik et al. 2013; Linthorst et al. 1990; Sela-Buurlage et al. 1993; Ward et al. 1991; Zavaliev et al. 2011). In $V$. vinifera, $16 \beta$-1,3-glucanases are present, but only five are basic proteins, and one of them contains both the $\mathrm{N}$ - and $\mathrm{C}$-terminal signal peptide sequences (Jaillon et al. 2007). Accordingly, $\beta$-1,3-glucanase genes can be classified into classes based on previous reports and it will be possible to compare their differential expression patterns in grapevines in response to pathogens in the near future.

In this study, five $\beta$-1,3-glucanase genes with differences in nucleotide sequences were found to exhibit differential expression in response to five different pathogens in $V$. flexuosa. These results provide useful information regarding grapevine defense responses at the molecular level and analysis of differential expression patterns of pathogenesisrelated genes under various pathogen infections. The data presented here will facilitate future investigations of modes of action and interaction between grapevines and pathogens that are also useful for breeding programs of grapevines resistant to diseases.

\section{ACKNOWLEDGMENT}

This work was supported by a grant from Next-Generation BioGreen (No. PJ008213), Rural Development Administration, Republic of Korea.

\section{REFERENCES}

Ahn SY, Kim SA, Jo SH, Yun HK. 2014. De novo transcriptome 
analysis of Vitis flexuosa grapevine inoculated with Elsinoe ampelina. Plant Genet. Res. (in print).

Ahn SY, Kim SA, Kim SH, Yun HK. 2012. Differential expression screening of defense related genes in Vitis flexuosa grapevine against Elsinoe ampelina and Rhizobium vitis. Korean to Kor. J. Intl. Agri. 24: 470-476.

Chang S, Puryear J, Cairney J. 1993. A simple and efficient method for isolating RNA from pine trees. Plant Mol. Biol. 11: 113-116.

Cheong YH, Kim CY, Chun HJ, Moon BC, Park HC, Kim JK, Lee SH, Han CD, Lee SY, Cho MJ. 2000. Molecular cloning of a soybean class III $\beta$-1,3-glucanase gene that is regulated both developmentally and in response to pathogen infection. Plant Sci. 154: 71-81.

Dobnik D, Baebler Š, Kogovšek P, Pompe-Novak M, Štebih D, Panter G, Janež N, Morisset D, Žel J, Gruden K. 2013. $\beta$-1,3-glucanase class III promotes spread of $\mathrm{PVY}^{\mathrm{NTN}}$ and improves in planta protein production. Plant Biotechnol. Rep. 7: 547-555.

Ebrahima S, Usha K, Singh B. 2011. Pathogenesis-related (PR)-proteins: Chitinase and $\beta$-1,3-glucanase in defense mechanism against malformation in mango (Mangifera indica L.). Sci. Hortic. Amsterdam130: 847-852.

El-kereamy A, El-sharkway I, Ramamoorthy R, Taheri A, Errampalli D, Kumar P, Jayasankar S. 2011. Prunus domestica pathogenesis-related protein-5 activates the defense response pathway and enhances the resistance to fungal infection. PLoS One 6: e17973.

Fang X, Chen W, Xin Y. 2012. Proteomic analysis of strawberry leaves infected with Colletotrichum fragaria. J. Proteomics 75: 4074-4090.

Fritig B, Heitz T, Legrand M. 1998. Antimicrobial proteins in induced plant defense. Curr. Opin. Immunol. 10: 16-22.

Giannakis C, Bucheli CS, Skene KGM, Robinson SP, Scott NS. 1998. Chitinase and $\beta-1,3$-glucanase in grapevine leaves: a possible defense against powdery mildew infection. Austr. J. Grape Wine Res. 4: 14-22.

Gill SS, Tuteja N. 2010. Reactive oxygen species and antioxidant machinery in abiotic stress tolerance in crop plants. Plant Physiol. Biochem. 48: 909-930.

Gupta P, Ravi I. Sharma V. 2013. Induction of $\beta$-1,3-glucanase and chitinase activity in the defense response of Eruca sativa plants against the fungal pathogen Alternaria brassicicola. J. Plant Interactions 8: 155-161.

Harish S, Kavino M, Kumar N, Balasubramanian P, Samiyappan
R. 2009. Induction of defense-related proteins by mixtures of plant growth promoting endophytic bacteria against Banana bunchy top virus. Biol. Control 51: 16-25.

Hatmi S, Trotel-Aziz P, Villaume S, Couderchet M, Clément C, Aziz A. 2013. Osmotic stress-induced polyamines oxidation mediates defense responses and reduces stressenhanced grapevine susceptibility to Botrytis cinerea. J. Exp. Bot. 65: 75-88.

Huffaker A, Kaplan F, Vaughan MM, Dafoe NJ, Ni X, Rocca JR, Alborn HT, Teal PEA, Schmelz EA. 2011. Novel acidic sesquiterpenoids constitute a dominant class of pathogen-induced phytoalexins in maize. Plant Physiol. 156: 2082-2097.

Ibraheem F, Gaffoor I, Chopra S. 2010. Flavonoid phytoalexindependent resistance to anthracnose leaf blight requires a functional yellow seed1 in Sorghum bicolor. Genetics 184: 915-926.

Jaillon O, Aury JM, Noel B, Policriti A, Clepet C, et al. 2007. The grapevine genome sequence suggests ancestral hexaploidization in major angiosperm phyla. Nature 449: 463-467.

Jayasankar S, Li Z, Gray DJ. 2000. In vitro selection of $V$. vinifera 'Chardonay' with E. ampelina culture filtrate is accompanied by fungal resistance and enhanced secretion of chitinase. Planta 211: 200-208.

Joosten MH, De Wit PJ. 1989. Identification of several pathogenesis-related proteins in tomato leaves inoculated with Cladosporium fulvum (Syn. Fulvia fulva) as $\beta-1,3-$ glucanases and chitinases. Plant Physiol. 89: 945-951.

Kemp G, Botha AM, Kloppers FJ, Pretorius ZA. 1999. Disease development and $\beta$-1,3-glucanase expression following leaf rust infection in resistant and susceptible near-isogenic wheat seedlings. Physiol. Mol. Plant Pathol. 55: 45-52.

Kombrink E, Somssich IE. 1995. Defense responses of plants to pathogens. Adv. Bot. Res. 21: 1-34.

Kortekamp A. 2006. Expression analysis of defense-related genes in grapevine leaves after inoculation with a host and a non-host pathogen. Plant Physiol. Biochem. 44: 58-67.

Krishnaveni S, Muthukrishnan S, Liang GH, Wilde G, Manickam A. 1999. Induction of chitinases and $\beta-1,3$-glucanases in resistant and susceptible cultivars of sorghum in response to insect attack, fungal infection and wounding. Plant Sci. 144: 9-16. 
Li M, Xu J, Qiu Z, Zhang J, Ma F, Zhang J. 2014. Screening and identification of resistance related proteins from apple leaves inoculated with Marssonina coronaria (EII. \& J. J. Davis). Proteome Sci.12: 7.

Li WL, Faris JD, Muthukrishnan S, Lui DJ, Chen PD, Gill BS. 2001. Isolation and characterization of novel cDNA clones of acidic chitinases and $\beta$-1,3-glucanases from wheat spikes infected by Fusarium graminearum. Theor. Appl. Genet. 102: 353-362.

Linthorst HJM, Melchers LS, Mayer A, Vanroekel JSC, Cornelissen BJC, Bol JF. 1990. Analysis of gene families encoding acidic and basic $\beta$-1,3-glucanases of tobacco. Proc. Natl. Acad. Sci. USA 22: 8756-8760.

Mauch F, Mauch-Mani B, Boller T. 1988. Antifungal hydrolases in pea tissue. II. Inhibition of fungal growth by combinations of chitinase and $\beta$-1,3-glucanase. Plant Physiol. 88: 936-942.

Neale AD, Wahleithner JA, Lund M, Bonnett HT, Kelly A, Meeks-Wagner DR, Peacock WJ, Denis ES. 1990. Chitinase, $\beta$-1,3-glucanase, osmotin, and extensin are expressed in tobacco explants during flower formation. Plant Cell 2: 673-684.

Payne G, Ward E, Gaffney T, Ahl Goy P, Moyer M, Harper A, Meins F, Ryals J. 1990. Evidence for a third structural class of $\beta$-1,3-glucanase in tobacco. Plant Mol. Bio. 115: 797-808.

Renault AS, Deloire A, Bierne J. 1996. Pathogenesis-related proteins in grapevines induced by salicylic acid and Botrytis cinerea. Vitis 35: 49-52.

Rivera ME, Codina JC, Olea F, de Vicente A, Perez-Garcia A. 2002. Differential expression of $\beta$-1,3-glucanase in susceptible and resistant melon cultivars in response to infection by Sphaerotheca fusca. Physiol. Mol. Plant Pathol. 61: 257265.

Roulin S, Buchala AJ. 1995. The induction of 1,3- $\beta$-glucanases and other enzymes in groundnut leaves infected with Cercospora arachidicola. Physiol. Mol. Plant Pathol. 46: 471-489.

Sela-Buurlage MB, Ponstein AS, Bres-Vloemans SA, Melchers LS, van den Elzen PJM, Cornelissen BJC. 1993. Only specific tobacco (Nicotiana tabacum) chitinases and $\beta$ -1,3-glucanases exhibit antifungal activity. Plant Physiol. 101: 857-863.

Simmons CR. 1994. The physiology and molecular biology of plant $\beta$-1,3-glucanases and 1,3; 1,4- $\beta$-D-glucanases. Crit. Rev. Plant Sci. 13: 325-387.

Thanseem I, Joseph A, Thulaseedharan A. 2005. Induction and differential expression of $\beta$-1,3-glucanase mRNAs in tolerant and susceptible Hevea clones in response to infection by Phytophthora meadii. Tree Physiol. 25: 1361-1368.

Venisse J-S, Malnoy M, Faize M, Paulin JP, Brisset MN. 2002. Modulation of defense responses of Malus spp. during compatible and incompatible interactions with Erwinia amylovora. Mol. Plant Microb. Interact. 15: 1204-1212.

Ward ER, Payne GB, Moyer MB, Williams SC, Dincher SS, Sharkey KC, Beck JJ, Taylor HT, Ahlgoy P, Meins F, Ryals JA. 1991. Differential regulation of $\beta$-1,3-glucanase messenger RNAs in response to pathogen infection. Plant Physiol. 2: 390-397.

Yoshikawa M, Yamaoka N, Takeuchi Y. 1993. Elicitors: their significance and primary modes of action in the induction of plant defense reactions. Plant Cell Physiol. 34: 1163 1173.

Yun HK, Park KS, Rho JH, Choi YJ, Kang KK. 2006. Evaluating the resistance of grapevines against anthracnose by pathogen inoculation, vineyard inspection, and bioassay with culture filtrate from Elsinoe ampelina. J. Am. Pom. Soc. 62: 97-103.

Yun HK, Rho JH, Park KS, Cha JS, Jeong SB. 2003. Screening system for crown gall resistance by pathogen inoculation in grapes. Kor. J. Hort. Sci. Technol. 21: 325-328.

Zavaliev R, Ueki S, Epel BL, Citovsky V. 2011. Biology of callose ( $\beta$-1,3-glucan) turnover at plasmodesmata. Protoplasma 1: $117-130$.

Zemanek AB, Ko TS, Thimmapuram J, Hammerschlag FA, Korban SS. 2002. Changes in $\beta$-1,3-glucanase mRNA levels in peach in response to treatment with pathogen culture filtrates, wounding, and other elicitors. J. Plant Physiol. 159: 877-889. 